\title{
Por uma ciência democrática e cidadã
}

\section{On behalf of a democratic and citizen science}

\section{En defensa de la ciencia democrática y ciudadana}

\author{
Kizi Mendonça de Araújo ${ }^{1, a}$ \\ kizi.araujo@icict.fiocruz.br | https://orcid.org/0000-0002-9378-3299
}

${ }^{1}$ Fundação Oswaldo Cruz, Instituto de Comunicação e Informação Científica e Tecnológica em Saúde, Laboratório de Pesquisa em Informação Científica e Tecnológica em Saúde. Rio de Janeiro, RJ, Brasil.

a Doutorado em Ciências pela Universidade Federal do Rio de Janeiro.

Palavras-chave: Avaliação da ciência; produção científica; produtivismo acadêmico; ciência cidadã; democracia.

Keywords: Science evaluation; scientific production; academic productivism; citizen science; democracy. Palabras clave: Evaluación de la ciencia; producción científica; productivismo académico; ciencia ciudadana; democracia.

O ano de 2018 foi emblemático, pois representou um ano de comemoração de várias conquistas importantes na busca de garantia de direitos sociais e humanos.

Na esfera internacional, destaca-se a comemoração dos 70 anos da Declaração Universal dos Direitos Humanos ${ }^{1}$, documento elaborado em 1948, pela Organização das Nações Unidas e seus Estados membros (entre eles, o Brasil), que estabelece os direitos e liberdades básicas capazes de garantir uma vida digna e o pleno exercício de cidadania a todos os seres humanos, independentemente de cor, raça, nacionalidade, orientação política, sexual ou religiosa. Cabe ressaltar também os 40 anos da Declaração de Alma-Ata, elaborada em 1978, como resultado da Conferência Internacional sobre Cuidados Primários de Saúde, que representa um marco nesse campo, pois traz uma nova e mais abrangente concepção de saúde, que passa a ser entendida como o "completo bem-estar físico, mental e social, e não simplesmente a ausência de doença ou enfermidade"”. $\mathrm{O}$ documento reforça a ideia da saúde como um direito fundamental do ser humano e como uma meta social mundial a ser atingida, ratificando a necessidade da participação social (individual e coletivamente) no planejamento e na execução dos cuidados de saúde para que esta meta seja integralmente atingida. Essa declaração aponta também para o papel central da pesquisa como instrumento para a resolução dos principais problemas de saúde que assolam as populações.

No âmbito nacional, celebramos os 30 anos da Constituição Federal (CF) de 1988², Carta Magna que marca o processo de redemocratização do Brasil, conhecida como Constituição Cidadã, dada a ampliação dos direitos e garantias individuais e sociais trazidas por ela e seu forte foco no combate às desigualdades sociais do país. Nesse sentido, a Constituição Cidadã estabelece, dentre outros, a garantia ao acesso à 
saúde e à educação como um direito fundamental do cidadão e um dever do Estado. Esse entendimento está na base da criação do Sistema Único de Saúde (SUS), que também comemora seu $30^{\circ}$ aniversário este ano. Tal sistema, ainda que longe da perfeição, possibilita a assistência à saúde gratuita a toda a população brasileira.

Entretanto, o ano também foi marcado por uma crise política e social sem precedentes na história recente do país, uma crise que tem colocado em xeque a manutenção dos direitos sociais conquistados ao longo de nossa história e que se configurou como elemento/assunto central do debate no nosso último pleito eleitoral.

Em meio a esse cenário, um depoimento chama a atenção: às vésperas das eleições presidenciais o rapper Mano Brown fez um discurso crítico e contundente sobre o distanciamento dos políticos no que se refere à população, que, de fato, deveria ser o foco das políticas governamentais, uma vez que somos regidos por um regime democrático, que pressupõe um "sistema político dedicado aos interesses do povo" 4 . Essa fala leva a uma reflexão sobre a atividade científica contemporânea e o distanciamento dos pesquisadores em relação à sociedade. Distanciamento, não restrito à divulgação dos resultados de pesquisa para o público não especialista, mas principalmente concernente à falta de interlocução, de troca, de imersão no território, fato que nos afasta das reais necessidades e prioridades de pesquisa da população. Produzimos conhecimento de forma hierarquizada, muitas vezes, sem entender se e como aquele conhecimento será incorporado às práticas sociais e à resolução de problemas.

Vivemos encastelados em nossos laboratórios, cada vez mais preocupados com a produção de papers, rankings, números e indicadores que norteiam a avaliação da ciência e do cientista; avaliação esta que nos confere reconhecimento e prestígio acadêmico. Preocupamo-nos, cada vez menos, com as aplicações dos resultados da pesquisa e com as consequências reais/sociais geradas por essa produção, em outras palavras, deixando à margem o compromisso social da ciência.

A incessante busca de adequação às normas da avaliação vigente, pautada no produtivismo ou taylorismo acadêmico, como alguns autores preferem denominá-la ${ }^{5,6}$, na internacionalização e no impacto das publicações vem modulando a atividade científica, causando impactos negativos, principalmente no tocante à responsabilidade social do cientista, gerando, segundo Gingras ${ }^{7}$, consequências mais severas nos países periféricos que tendem a nortear a atividade científica para atender aos critérios estabelecidos pelos países centrais, escolhendo temas de pesquisa de interesse internacional em detrimento aos temas/ problemas locais, que não têm repercussão internacional. Esse mesmo direcionamento afeta diretamente a escolha do periódico para a publicação, que tem sido pautada pelo Fator de Impacto do periódico ou pelo estrato Qualis, ambos fortemente associados aos padrões internacionais de pesquisa, e não pelo público com quem deveria dialogar ou ao qual deveria se dirigir.

Nesse sentido, Oliveira aponta que o sistema de avaliação atual, no qual prevalece a lógica mercantilista do "publicar ou perecer", inviabiliza o exercício da responsabilidade social do cientista, exercício que, segundo o autor, exige uma reflexão sobre as práticas científicas, seu significado e suas consequências sociais.

Precisamos refletir, enquanto comunidade acadêmica, que ciência estamos fazendo. Para que e para quem estamos produzindo conhecimento?

Retoma-se aqui a fala do Mano Brown: "O Partido do povo tem que entender o que o povo quer", "se não sabe, volta pra base e vai procurar saber”. Uma ciência voltada para promoção da cidadania e resolução de problemas sociais tem de buscar entender as reais necessidades da população; este é o compromisso social da ciência! Para tal, é imperativo uma aproximação, a criação de pontes entre a academia e a sociedade (ponte no sentido de troca - via de mão dupla), com vistas a fomentar a participação social no processo de construção de conhecimento e possibilitar de fato a construção de uma ciência cidadã.

Aqui fica o questionamento e o convite à reflexão: que ciência queremos fazer? 
Em nome da equipe editorial, desejo a todos uma ótima leitura e que, em 2019, possamos caminhar rumo à construção de uma ciência de fato democrática e cidadã, capaz de contribuir efetivamente para a conquista das garantias fundamentais traçadas em nossa constituição.

\section{Referências}

1. Unicef (BR). Declaração Universal dos Direitos Humanos [Internet]. 1948 [citado 2018 nov 19]. Disponível em: https://www.unicef.org/brazil/pt/resources 10133.htm.

2. Declaração de Alma-Ata. Conferência Internacional sobre cuidados primários de saúde; 6-12 de setembro 1978; Alma-Ata; USSR. [citado 2018 nov 19]. Disponível em: http://cmdss2011.org/site/wpcontent/uploads/2011/07/Declara\%C3\%A7\%C3\%A3o-Alma-Ata.pdf.

3. Presidência da República (BR). Constituição: República Federativa do Brasil 1988 [Internet]. Brasília (DF); 1988. Disponível em: http://www.saude.am.gov.br/planeja/doc/constituicaofederalde88.pdf. Acesso em: 19 nov. 2018.

4. Dicionário on-line Michaelis. Democracia. [citado 2018 nov 19]. Disponível em: https://michaelis.uol. com.br/moderno-portugues/busca/portugues-brasileiro/democrACIA/.

5. Domingues I. O sistema de comunicação da ciência e o taylorismo acadêmico: questionamentos e alternativas. Estudos Avançados. 2014;28(81):225-250.

6. Oliveira MB. A avaliação neoliberal na universidade e a responsabilidade social dos pesquisadores. Scientiae Studia. 2008; 6(3):379-87.

7. Gingras Y. Os desvios da avaliação de pesquisa: o bom uso da bibliometria. Rio de Janeiro: Editora UFRJ; 2016. 